\title{
ICT APPLICATION IN NATURAL SCIENCE EDUCATION
}

\section{Vlasta RABE - Jan ŠLÉGR}

\begin{abstract}
This paper is focussed on effective approach to teaching and learning in education, especially disciplins in natural and engineering science. There are shown innovative approaches to teaching process, impact of ICT in teaching and learning, e.g. e-learning, collaborative learning and blended learning. There is accented pedagogical and psychological aspect of students motivation in engineering disciplins and ICT influence in development of key competences.
\end{abstract}

Key words: effective approach to teaching and learning, natural science, impact of ICT, motivation, key competences.

\section{VYUŽITÍ ICT VE VÝUCE PŘÍRODOVĚDNÝCH DISCIPLÍN}

Resumé: Článek je zaměřen na efektivní přistup $k$ výuce a sebevzdělávání, zejména v přirodovědných a technických disciplinách. Jsou zde ukázány inovačni př́stupy ke vzdělávacímu procesu, vliv ICT ve výuce, jako např. e-learning, kolaborativní učení a blended learning. Dưraz je kladen na pedagogické a psychologické aspekty pro motivaci studentì v technických predmětech a vliv ICT v rozvíjení kličových kompetencí.

Klíčová slova: efektivni prístup $k$ výuce a sebevzdělávání, přirodní vědy, vliv ICT, motivace, klíčové kompetence.

\section{1 Úvod}

V současné době prudké informační exploze a při existenci heterogenní struktury informačních zdrojů relevantních pro potřeby odborných a technických disciplín a jejich expertů se jeví jako nutnost neustávající inovace obsahové a procesní stránky odborných disciplín. Obrovské množství nových poznatků, které můžeme každodenně čerpat $\mathrm{z}$ různých informačních zdrojů, zejména internetu, nám nedovolí ani registrovat všechny novinky, týkající se některých speciálních oblastí prírodních věd. $Z$ tohoto důvodu je potřebné zavádět změny do vyučování nejen technických předmětů. Úlohou oborových didaktik není jen inovace a revize obsahu vyučování, ale také modernizace metod používaných $\mathrm{v}$ pedagogické praxi. Přitom se nejedná o pouhou implementaci vědeckých poznatků do vyučovacího procesu, ale o jejich promyšlenou transformaci $\mathrm{z}$ hlediska podmínek a cílů pedagogické činnosti.

\section{Didaktické principy v technických předmětech}

Oborová didaktika technických předmětů vychází z obecných didaktických principů, které se konkretizují $\mathrm{v}$ podmínkách výuky. Zaměřuje se tedy na cíle, obsah, principy, metody, organizační formy a plánování vzdělávání a vyučování, ve snaze aplikovat tyto principy jak ve vyučování technických předmětů, tak v praktické činnosti, a syntetizovat poznání směřující $\mathrm{k}$ řešení konkrétních praktických úloh (Riedl, 2003). Z hlediska obsahové stránky spočívá modernizace výuky ve vytvoření podrobného plánu včetně cílů, kterých má být dosaženo, v systematickém, názorném a logickém uspořádání učiva, reflektujícím individuální zvláštnosti studentů. Z hlediska forem výuky se osvědčuje forma dialogu, podpora týmové práce a zdůrazňování smysluplnosti vyučovaných předmětů pro praktické uplatnění.

\section{Týmová spolupráce jako metodika}

Budování týmů a týmová práce se uplatňuje při probírání věcných témat i jako metodika. Dialog je pokládán za metodu komunikace a společné myšlení. Jako metoda práce v laboratoři ve smyslu humanistické psychologie může být využita metoda TCI (interakce zaměřená na téma), kterou vypracovala Ruth Cohn pro situace učení nebo vedení lidí (Riel, 2000).

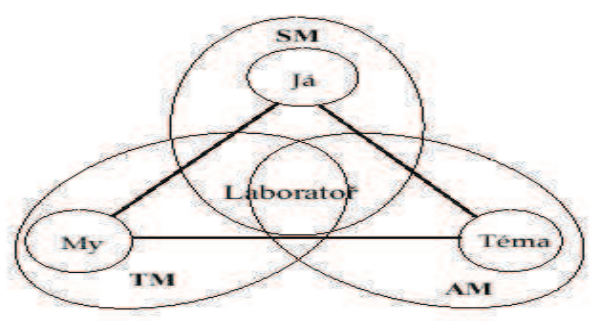

Obr 1: Metoda TCI 


\section{Vliv informačních a komunikačních technologií ve vzdělávání}

V informační společnosti vznikají nové společenské požadavky na vzdělávání. Práce $\mathrm{s}$ informacemi, jejich sdílení a prezentace se stává součástí každodenního života. ICT, počítačové sítě a informační služby typu celosvětové informační sítě WWW umožňuji mnohem širší informační základnu, ze které lze čerpat, než tomu bylo kdykoli v minulosti. Proto by měl výukový proces zdůraznit schopnost práce $\mathrm{v}$ týmech (např. při projektovém učení), adaptovat se na změny a nové skutečnosti. Od studentů to vyžaduje schopnost kriticky hodnotit získané informace a zaujímat postoj $\mathrm{k}$ jejich obsahu, což nabývá větší důležitosti než pamět'ové výkony zaměřené na memorování obsahu učebnic. V digitálním světě vzniká řada produktů vhodnou kombinací dílčích řešení, která jsou v sít'ovém prostředí dostupná, a takový model se velmi dobře může uplatnit $i$ při sestavování nových vzdělávacích programů či učebních materiálů. Nové souvislosti, které lze tímto způsobem odkrývat, se mohou uplatnit jako výrazný motivující a inspirační prvek (Vybíral, 2006).

Možností inovace kvalifikované didaktické formy výuky je řešení pomocí e-learningu. Toto řešení podporuje učební procesy, při nichž studenti mohou mít při řešení zadaných úkolů učební látku, čas a pracovní tempo individuální. Prostředky výpočetní techniky umožňuji simulace složitých jevů, ale rovněž mohou prohlubovat a zkvalitňovat motivaci a zpětnou vazbu studentů (Černák, 2007).

\section{Specifika odborných a technických předmětů}

Jedním z podstatných úkolů učitele odborných předmětů je vysvětlovat teoretický obsah $\mathrm{v}$ různých souvislostech, $\mathrm{v}$ nějaké prakticky navozené situaci, která simuluje aspekty skutečného světa, se zaměřením na budoucí práci studentů. Studenti pak jsou schopni reagovat na nové skutečnosti a vyvíjet nové koncepty, opětovně používat nabyté zkušenosti pro snadnější porozumění novým problémům, a aplikovat efektivně současné produkty ICT ve výzkumu a vývoji. Zároveň tak dobře porozumějí vyučované disciplíně a přitom se stanou profesionály $\mathrm{v}$ oblasti informatiky. Je kladen důraz na praktické vyučování a učení se jako nástroje pro implementaci metody „learning by doing“ (učení činností), spolu s „experiential learning“" (zkušenostním učením), (Rabe, 2008).

\section{Simulace s využitím ICT}

Vzhledem k tomu, že realizace všech pokusů by byla časově náročná, je často vhodné využít počítače pro simulaci ve formě animovaných nákresů. Studenti mají možnost řešit hypoteticky průběh pokusu a $\mathrm{k}$ tomu analyzovat známé poznatky. Použití simulací může být efektivní např. i před laboratorními pracemi, kde studenti mají možnost vidět, jak by měla být správně sestavená aparatura a již předem vědí, jak bude pokus probíhat.

V rámci předmětu Programování si studenti mohou vytvořit $\mathrm{v}$ prostředí Delphi řadu programů, znázorňujících fyzikální a chemické pokusy. Při projektování jednoduchých informačních systémů $\mathrm{v}$ předmětu Informatika 3 mohou studenti pomocí zvoleného CASE nástroje vytvářet simulační modely. Simulační model může reálný život projektu nahradit napřr. manažerovi, který si zvyšuje kvalifikaci. Hovoříme pak o simulačních projektových trenažérech apod. Student (či trénující manažer projektů) ř́íí projekt a místo skutečnosti mu na jeho řídící zásahy odpovídá simulační model (Mildeová, 2003). Je to bezpečné, levné, opakovatelné. Skutečné př́íciny chyb i úspěchů lze pak zpravidla snadno dohledat. Následně je velmi účelné př́ímé využití simulačního modelu při řízení nějakého projektu a jeho rizik. Simulace se může uplatnit, byt' rozdílným způsobem, ve všech fázích životního cyklu projektu.

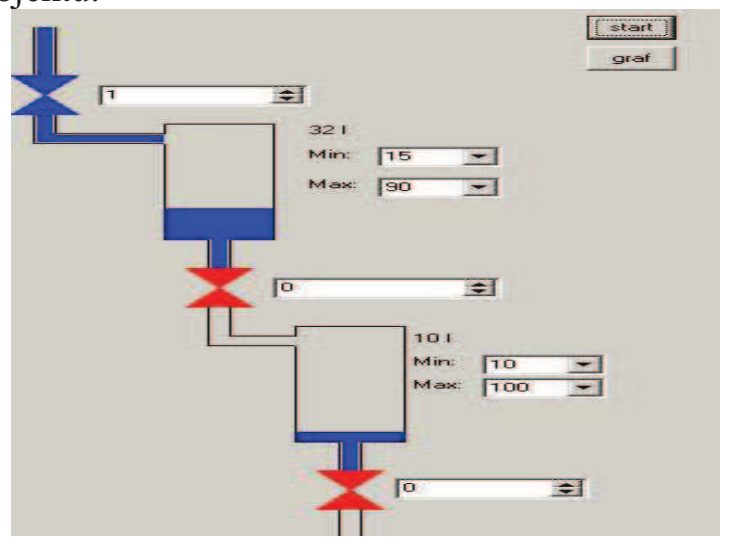

\section{Obr 2: Simulace pokusu s nádobami (program v Delphi)}

\section{Rozvíjení klíčových kompetencí}

Rozvíjení a osvojování všech klíčových kompetencí přesahuje rámec základního vzdělávání a týká se všech dalších stupňů, včetně celoživotního vzdělávání. Je potřeba si ale uvědomit, že na každém stupni se tyto kompetence liší po stránce obsahu i formy. 
Klíčové kompetence lze definovat jako soubor požadavků na vzdělávání, zahrnující podstatné vědomosti, dovednosti, a schopnosti univerzálně použitelné $\mathrm{v}$ běžných pracovních a životních situacích. Jako cílová kategorie jsou kompetence podstatným východiskem a předpokladem pro stanovení vzdělávacího obsahu i podmínek nejen v technickém vzdělávání.

\section{Závěr}

Informační a komunikační technologie mají značný vliv na současný vývoj výukových metod nejen $\mathrm{v}$ př́rodovědných disciplínách. V současné době převládá snaha zapojovat technologie do výuky spíše konstruktivním způsobem. Př́nos technologií spočívá především $\mathrm{v}$ urychlování a umocňování výukových procesů. Vhodně realizovaná didaktická transformace, tj. výběr poznatků a jejich zpracování na systém vědomostí, dovedností, myšlenkových postupů a operací, hodnot a vlastností osobnosti, které si má student osvojit pod vedením učitele, může výrazně zvýšit kvalitu výuky, jak po obsahové stránce, tak po stránce samotného vyučovacího procesu. Jde tedy o výběr vhodného postupu pro přizpůsobení obsahu vzdělávání psychice, potřebám a zkušenostem studentů. V technických předmětech je potřeba zaměřit pozornost zejména na systematičnost uspořádání obsahu výuky, názornost a výběr vhodných metod, podporujících aktivní učení studentů.

\section{Literatura}

[1] RIEDL, A. Didaktik II - Berufliche Bildung. München : Technische Universität, 2003.

[2] RIEL, M.: The future of technology and education: Where are we heading? in: Watson, D. M. \& Downes, T. (Eds.) Communications and Networking in Education. Boston, MA: Kluwer Academic Press, 2000, pp 9-24.

[3] VYBÍRAL, B.: Technické aplikace fyziky motivační činitel procesu poznávání. Referát na mezinárodní konferenci DIDFYZ, 2006. Račkova dolina.
[4] ČERNÁK, I., MAŠEK, E. Základy elektronického vzdelávania. Vysokoškolská učebnice, Ružomberok 2007. s.343, ISBN 97880-8084-1713.

[5] RABE, V., JEHLIČKA, V.: E-learning and blended learning at the university. ED-MEDIA, Vienna, 2008, ISBN: 1-880094-62-2.

[6] MILDEOVÁ, S., VOJTKO, V. Systémová dynamika. 1. vyd. Praha : Oeconomica, 2003. ISBN 80-245-0626-2.

[7] CLIFFORD, J.: Composing in stages: The effects of collaborative pedagogy. Research in Teaching English 15 (1), 1981, pp. 37-44.

[8] Knowledge: Its Creation, Distribution and Economic Significance (Vol.2. The Branches of Learning). Princeton, N.J.: Princeton University Press, 1982.

[9] PRŮCHA, J. Moderní pedagogika. Praha: Portál, 1997. ISBN 80-7178-170-3.

[10] ANDERSON, L. et all.: A Taxonomy for Learning, Teaching a Assessing of

Educational Objectives. New York: Longman, 2001, $352 \mathrm{~s}$.

[11] ZELENICKÝ, L'. Nové trendy v prírodovednom vzdelávaní. In: Technológia vzdelávania. č. 12,2000 , s. 8 - 11. Nitra: Slovidac, 2000.

[12] McLUHAN, M. Understanding media - the Extension of Man. New York: McGraw Hill, 1964. ISBN: 0262631598.

Mgr. Vlasta Rabe, Ph.D.

Katedra informatiky

Mgr. Jan Šlégr

Katedra fyziky

Př́rodovědecká fakulta UHK

Rokitanského 62

50003, Hradec Králové, ČR

Tel: +420 4933311170

E-mail: vlasta.rabe@uhk.cz, jan.slegr@uhk.cz Www pracovišstě: www.uhk.cz 